\title{
Perception of Flipped Classroom Model among Year One and Year Three Health Science Students
}

\author{
D. Sinouvassane and A. Nalini
}

\begin{abstract}
Aim: The purpose of this study was to compare the perception of the flipping classroom model between the first year and third year health science degree students. Design: A total number of 51 students $(n=24$ from year one and $n=27$ from year three) from degree physiotherapy programme. Year one and year three students were enrolled for pathology and cardio respiratory courses respectively. The flipped classroom model was introduced for the first time to students during the same teaching semester by the same instructor. Students were requested to read posted online materials of their respective courses which included a brief introduction of the topic, video podcasts and frequently asked questions related to the topic. Students were instructed to respond the questions posted, prior to the scheduled face-to- face class. The instructor discussed during the contact session. The participants feedback and their perception about this method were obtained by using a questionnaire. Result: Perception about the flipped class was different among the first and final year students. Conclusion: This study found that the year one students are open to accept the flipped classroom model when compared to the third year students.
\end{abstract}

Index Terms - Flipped classroom, video podcast, traditional classroom, facebook, blackboard, online.

\section{INTRODUCTION}

Long ago was the time when students used to be the elements of passive listening and reciprocating information given to them. Traditional teaching methods are definitely basic ways of imparting knowledge, but are we sure if these methods are the appropriate ones for the students of today's era? The generation of today also frequently known as 'Millennials' or 'generation Y' are influenced by technology where access to information is just a click away in the form of iPad and iPhones where they are unconsciously competent. The typical characteristics of the tech savvy students are being optimistic, purpose driven, require instant and constant feedback, and expect rapid promotion and recognition of their efforts. These people need to be handled in a rather tactical way where the knowledge dissemination is important not compromising the 'fun' element as required by them. As instructors in today's world we are expected to design classroom strategies in such a way that the students are actively engaged and interactive, as well as, we subtly provoke the active thinker and performer in them. Such an education promises to develop a student as a problem solver. Research has supported that active learning strategies result in higher student engagement and greater learning gains as

Manuscript received July 10, 2014; revised October 21, 2014.

The authors are with the INTI-Laureate International Universities, Malaysia (e-mail: sinouvassane.d@newinti.edu.my). compared to traditional instructor centred methods such as lecture [1].

Allowing students to learn on their own may pose a problem of students being very casual and not oriented towards learning. On the other hand lectures alone may transform them to turn out as passive listeners. The question then arises as how much are we supposed to teach? How much do we allow them to learn by their own? Here comes the tool called "flipped classroom" which is also known as inverse, reverse, backwards classroom, which hints the answer to the previous questions. In the words of the pioneers of the flipping classroom concept Aaron Sams and Jonathan Bergmann, "In this model of instruction, students watch recorded lectures for homework and complete their assignments, labs, and tests in class. Flipping the classroom involves providing instructional resources for students to use outside of the class so that class time is freed up for instructional activities" [2]. In flipped classroom model what is normally done in class and what is usually done as homework are interchanged. This method gives the freedom of allowing the students to get to know the contents of the class according to their convenience at their own time pace. Teaching students at higher education levels holds the responsibility of preparing them to face the tomorrow's world. We are required to develop cardinal skills such as critical thinking, creativity, communications and collaboration which are encouraged by activities employed while using flipped classroom model [3]. When we are unable to cater as per the specific needs of the market stakeholders, implying the current education system is deficient. The core competency skills of higher education such as critical thinking, written communication and complex reasoning skills are not learned by today's students [4]. This in turn leads to the higher unemployment rates, report lower lifestyle satisfaction, and a mass higher credit card debt than their more accomplished peers due to less acquired critical thinking skills. [5]. Active learning strategies are proven to be stimulating higher-order thinking, problem solving, and critical analysis [6].

The use of flipping classroom in medical and health sciences have been used for different subjects such as pharmaceutics, embryology, surgery, critical care, pathology, epidemiology and so on. A research conducted at the University of North Carolina reveals that students had a better understanding, application of key concepts and were confident in their ability to apply the knowledge and skills they developed. There was also significance in terms of attendance which was higher while using a flipped classroom model. The majority of the students had also strongly agreed there was a remarkable enhancement in their learning [7]. The importance of incorporating the methods of active learning is also emphasized by a study done at the College of Allied 
Health and Nursing at the Nova Southeastern University, infers that today's health science instructors are challenged because they need to lay the basic meaningful knowledge which the students can apply in clinical reasoning rather than blindly following the usual protocol solutions [8].

After being used to a way of learning, it takes time for students to acknowledge and inculcate the new way of learning. Change is not easily acceptable when one is used to years of practice in a comfortable zone. Students as well as instructors take time to accept and accommodate to flipped classroom model. Flipped classroom would have faced its share of oppositions from students as well as academic critics. This study aims to compare the perception of the flipping classroom model between year one and year three health science students. From this study we expect year one students who are new to the university education and their perception towards the flipped classroom model would be a positive approach, whereas year three students being used to the traditional classroom teaching were anticipated to resist the new learning approach.

\section{RESEARCH AIMS}

Study the student's perception on flipped classroom.

Explore differences in perception of the flipping classroom model among year one and year three students.

\section{MATERIALS AND METHODS}

This research aims are explored through a systematic study conducted among 51 undergraduate physiotherapy students.

This study involved 27 students from year three and 24 students from year one enrolled for cardio respiratory science and pathology course respectively. Flipped classroom approach was introduced first time in both the classes in the same semester by the same instructor. Online forums for the specific classes were created by the instructor in facebook and Blackboard. The instructor posted the study materials, including the brief introduction of the lecture topic, video podcasts, application and problem solving questions related to the lecture topic, on the online forum for the specific courses one week prior to the scheduled class. Instructions were posted online to view study materials for the week and were instructed to answer the questions posted online, one student must answer for one posted question, within a specific time frame.

The peers were asked to grade and comment on the answers posted by their classmates, one student must grade and comment for one answer online prior to the scheduled face-to-face class. The instructions for grading were posted by the instructor on the forum such as strongly agreeable (10 points) where the students answer the question completely and support with research evidence, agreeable ( 7 points) is given when the answer is complete but no research data, partially agreeable (5 points) incomplete or related answer for the question and not agreeable ( 2 points) where the points are given for participation.

The instructor observed the whole online activity until the scheduled lecture and any queries on the posted materials and questions were clarified by the instructor. The lecture classes were used for discussing, debating and justifying the grades of the posted answers, reviewing the case studies and also learning the deeper aspects of the topic. Answering the posted questions, grading and commenting on the posted answers were rewarded with scores. The cumulative scores were considered for assignment marks.

The questionnaire was used to obtain student feedback on flipped classroom teaching model at the end of the semester. The participants were asked to grade the questions from 1 to 5 , where 1 for strongly disagree, 3 for neutral and 5 for strongly agree.

\section{RESULTS AND DISCUSSION}

A total of 51 students, $n=24$ from year one and $n=27$ from year three, were participated in the survey.

The eight main criteria used to compare the responses from year one and year three students were related to 1) understanding of the course content ;2) searching for online information; 3) collaborative learning; 4) dependency on the instructor; 5) peer evaluation; 6) personal development ; 7) comparison of flipping over conventional teaching; 8) active participation in flipped classroom. The survey results are summarized in Table I.

The mean score out of 5.0 for each criterion was calculated individually for year one and year three class. The mean score of 3.0 is considered as neutral, more than 3.0 as agreeable while less than 3.0 as disagreeable.

Based on the data, it is evident that year one students agreed that the study materials posted online helped them to understand the course contents better (score: 4.2) while year three students reflected neutral position (3.0).

The implementation of flipping has increased the online course information searching ability for year one students (score 4.3) but not significantly for year three students (score; 3.1). Interestingly year one students (score: 4.1) had accepted that flipped classroom has enhanced the collaborative learning where they can learn from their peer's answers and comments, while no remarkable enhancement was observed among year three students (score 3.1).

Posting online instructions and study materials were expected to reduce the dependency on the instructor, this expectation was fulfilled among year one students (score 3.7) but not fulfilled by year three students (score: 2.3 ).

Peer marking was observed to be the most interesting part in the whole activity, where the year one students liked the peer marking, which was also supported by the survey score (score: 4.2). The year one students argued in class for the grade given by peers and the peers had to justify it. The peer marking process was believed to enhance the student's learning process by motivating them. But this pattern was not observed in year three class and the peer marking was not favoured (score: 2.2 ).

The students had been independent in reviewing the materials posted online, searching for the answers to the posted questions from texts / journals/ online sites, and also reviewing, commenting and grading the peer's answers online before the actual lecture. These activities were believed to help the personal development of the students, which was 
supported by year one students (score: 4.0) whereas rejected by year three students (score: 2.6).

TABLE I: FEEDBACK FROM THE STUDENTS

\begin{tabular}{|c|c|c|c|}
\hline No. & Survey Question & $\begin{array}{l}\text { Year one } \\
\text { students } \\
\text { Mean } \\
\text { Score out } \\
\text { of } 5.0 \\
\end{array}$ & $\begin{array}{l}\text { Year three } \\
\text { students Mean } \\
\text { Score out of } \\
5.0\end{array}$ \\
\hline 1 & $\begin{array}{l}\text { Study materials posted online } \\
\text { have helped me to understand } \\
\text { the course contents better }\end{array}$ & 4.2 & 3.0 \\
\hline 2 & $\begin{array}{l}\text { Flipped classroom learning } \\
\text { has increased my online } \\
\text { course information searching } \\
\text { ability }\end{array}$ & 4.3 & 3.1 \\
\hline 3 & $\begin{array}{l}\text { I learnt more by collaborating } \\
\text { with others by online sharing } \\
\text { and commenting }\end{array}$ & 4.1 & 3.1 \\
\hline 4 & $\begin{array}{l}\text { Flipped classroom learning } \\
\text { has reduced my dependency } \\
\text { on the lecturer }\end{array}$ & 3.7 & 2.3 \\
\hline 5 & $\begin{array}{l}\text { Peer evaluation is a good } \\
\text { practice for the assessment of } \\
\text { flipped classroom learning } \\
\text { activity }\end{array}$ & 4.2 & 2.2 \\
\hline 6 & $\begin{array}{l}\text { Flipped classroom learning } \\
\text { has helped my personal } \\
\text { development }\end{array}$ & 4.0 & 2.6 \\
\hline 7 & $\begin{array}{l}\text { I learnt more from flipping } \\
\text { and I prefer flipped class over } \\
\text { conventional teaching }\end{array}$ & 4.2 & 2.6 \\
\hline 8 & $\begin{array}{l}\text { Did you actively participate in } \\
\text { the flipped classroom? (Yes / } \\
\text { No) }\end{array}$ & $\begin{array}{l}88 \% \\
(4.4)\end{array}$ & $59 \%(3.0)$ \\
\hline
\end{tabular}

We believed that the flipping the classroom would be a better approach over conventional teaching according to the study which indicated that classroom flip had a positive impact on student learning, the students perceived the method of study as more effective than lecturing and reported that the students enjoyed the class and benefited from watching videos outdoor [9]. This belief is proven by year one students (score: 4.2) and challenged by year three students (2.6).

$88 \%$ of year one students reported that they had participated actively in flipped classroom approach while only $59 \%$ of year three students were active in this flipping approach. The variation in the domain scores are depicted in Fig. 1.

\section{A. Student's Opinion on Flipping}

When the students were requested to post comments about their opinion on flipped classroom activities, year one students appreciated flipped classroom activities by sharing their comments online, but no feedback comments were received from year three students which revealed their nonpreference.

From year one student's comments, it is observed that the students had appreciated: 1) Approach of learning by watching video podcasts which gave them better understanding of the course content and improved learning, which is evident from the earlier studies that students found online video and powerpoint materials were useful and more interesting [10]. Flipped classroom with use of videos that engage and focus students learning offers a new model for case study teaching combining with active student centred learning [11]. 2) Flexibility in learning time which allowed the students to learn on their own pace as stated by Fulton that flipped classroom allow students to move at their own pace and access instruction at any time [12], here the students learn when they want to learn and not forcing them to learn in the class when they are not ready to receive any information from the class. 3) Critical thinking and application based questions posted have increased their learning and makes them remember better on what they have learnt.

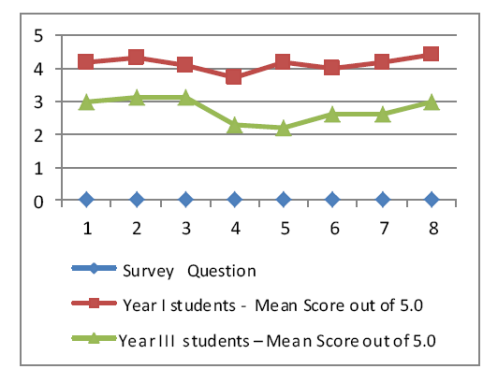

Fig. 1. Comparison of the criteria between year one and year three students.

\section{B. Few Comments from Year One Students (Unedited)}

Student 1 - "It was kinda different way of learning. actually, learning from the videos gave $\mathrm{u}$ a better overall understanding of the particular topic. Now, we $r$ going more towards technology based learning programs, whereby what i found is, this type of online activity is one among them, whereby it gives u a relaxed way of learning!"

Student 2 - "For myself I found it is very interesting way to study and easy to remember what we have studied it was fun to study online. And thanks for giving us this chance MR. Sino Djearamane."

Student 3 - "The online learning was very different compared to the conventional classroom. I liked the flexibility of answering the questions whenever $\mathrm{i}$ want during a certain time period and the application questions actually made me use by brain cells more: P It also helped me understand the subject better. The videos were pretty informative too."

Student 4 - "I found the online activity fun and very interesting, compared to just sit in class and listen to lectures, it was even challenging to answer the questions posted. Learning by watching videos in fact gave me a better understanding on each topic, even till today I can still remember what my topic was all about. It was really good and helpful for me :) I enjoyed doing this activity."

\section{Experience of the Instructor on Flipping}

Use of flipped classroom made students to learn the basic concepts effectively by viewing the posted study materials before the class, which gave more room for the instructor to concentrate on the critical part of the lecture, application knowledge and problem solving skills during the class time as recommended by Milman who identified that the flipping allows increased class time for more engaging instruction, increased students engagement and focused classroom discussion [13]. The questions on the watched videos appeared to be a strong motivator of the learning process, which also promoted students engagement and class attendance where the students had to come to the class to defend for the given grade. Additionally the online forum was very useful to effectively communicate the information such as postponement of class or test due to unforeseen reasons and any other announcements regarding any extra- curricular activities. 


\section{Challenges Faced with Year Three Students}

Students Resistance: Being taught by traditional classroom teaching previously, year three students were introduced to flipped classroom for the first time. Students resisted the new approach by stating that, they were not used to the model, required to spend lot of time online, found it difficult to find the online study materials, and had more content to read and understand, also felt it was more stressful coming to class without reviewing the posted online materials. This kind of student's resistance on flipping had been reported in Flipped Classroom Case Study. University of Queensland, Australia [14].

Student Evaluation Score: It was observed that the student's evaluation score for the instructor from year three students was low, in contrast with the score from year one students. It is unclear whether the low score is due to student's resistance to new teaching approach or dislike due to course content delivery, as the same scenario had been observed in Flipped Classroom Case Study. University of Queensland, Australia [14].

Internet Connectivity: The majority of the year three students had issues relating to internet connectivity being unable to view and participate in the flipped classroom activities within specific timeline. The same difficulty was also claimed by few of the students from year one.

\section{LiMiTATIONS}

Comparison was not done among the students enrolled for the same course. The level of understanding, difficulty and comprehension might differ between year one and year three courses.

\section{CONCLUSION}

This study result shows that implementing flipped classroom had been appreciated by year one students, since the students were new to the university education and open to accept the new teaching approaches. While the year three students resisted, maybe due to the facts that they are already conditioned to the traditional classroom teaching for the previous two years. They opined being taught by the lecturer face-to-face was simpler and easier than flipped classroom, because they had to take the initiative to review the teaching materials on their own. Hence it's recommended to implement flipped classroom model from year one of the university education, paving way for better acceptance among students.

\section{ACKNOWLEDGMENT}

We would like to thank Prof Dato' Dr. Ibrahim Ahmad Bajunid, Deputy Vice Chancellor \& Dean of Health Sciences faculty, Mr. J. S. Praveen, Head of the Physiotherapy program for supporting and encouraging the research study and special thanks to Prof. Narasimman Swaminathan and $\mathrm{Mr}$. Vinodhkumar for the valuable suggestions and guidance. Most importantly we also extend our gratitude to the students of physiotherapy but for whom this study would have been impossible.

\section{REFERENCES}

[1] M. Prince, "Does active learning work? A review of the research," Journal of Engineering Education, vol. 93, no. 3, pp. 223-23, 2004.

[2] J. Enfield, "Looking at the impact of the flipped classroom model of instruction on undergraduate multimedia students at CSUN," Tech. Trends, vol. 57, no. 6, pp. 14-27, 2013.

[3] P. Restad, "Flipped learning in higher education," Always Learning, 2013.

[4] R. Arum and J. Roska, Academically Adrift: Limited Learning on College Campuses, Chicago, Ill: University of Chicago Press, 2010.

[5] R. Arum, E. Cho, J. Kim, and J. Roska, Documenting Uncertain Times: Postgraduate Transitions of the Academically Adrift Cohort, New York, NY: Social Science Research Council, 2012.

[6] J. D. Bransford, A. L. Brown, and R. R. Cocking, How People Learn: Brain, Mind, Experience, and School, Washington University, 1991.

[7] W. J. McKeachie, P. R. Pintrich, Y. G. Lin, and D. A. Smith, Teaching and Learning in the College Classroom: A Review of the Literature, Mich: University of Micichigan Press, 1986.

[8] McLaughlin et al., "The flipped classroom: A course redesign to foster learning and engagement in a health professions school," Academic Medicine, vol. 89, no. 2, February 2014.

[9] S. Zappe, R. Leicht, J. Messner, T. Litzinger, and H. Lee, "Flipping the classroom to explore active learning in a large undergraduate course," in Proc. the 2009 American Society for Engineering Education Annual Conference and Exhibition.

[10] K. W. Ruddick, "Improving chemical education from high School to college using a more hands-on approach," Doctoral dissertation, University of Memphis.

[11] C. F. Herreid and N. A. Schiller, "Case studies and the flipped classroom," Journal of College Science Teaching, vol. 42, no. 5, 2013.

[12] K. Fulton, "Upside down and inside out: Flip your classroom to improve student learning," Learning \& Leading with Technology, vol. 39 , no. 8 , pp. $12-17,2012$.

[13] N. Milman, "The flipped classroom strategy: What is it and how can it be used?" Distance Learning, vol. 9, no. 3, pp. 85-87, 2012.

[14] Flipped Classroom Case Study, University of Queensland, Australia.

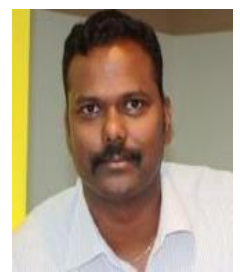

Sinouvassane Djearamane was born in Puducherry, South India, on October 31, 1978. He earned his bachelor degree in medical laboratory technology (1999) from Jawaharlal Institute of Postgraduate Education and Research (JIPMER) under Pondicherry University, masters in biochemistry (2007) from Allahabad Agriculture Institute Deemed University and also he holds master of philosophy in biochemistry (2008) from Vinayaka Missions University, India.

Sinouvassane is presently working as a senior lecturer \& the head for clinical laboratory science discipline in the Faculty of Health Sciences at INTI-Laureate International Universities, Malaysia. He has taught the students of health science programmes over 5 years in Malaysia and 4 years in India. He presented three research papers on teaching and learning methodologies in health sciences.

Sinouvassane has received "Vice Chancellor's Award for Innovative Teaching for the Year 2013" from INTI International University. Also "the best outgoing student" and "outstanding performance" award for his undergraduate degree by JIPMER and Pondicherry University respectively in 1999 .

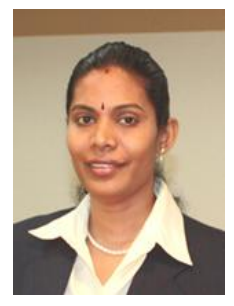

A. Nalini was born Chennai, Tamil Nadu, on March 29, 1978. She held a bachelor's degree in physiotherapy (1999) and master's degree in physiotherapy (2005) specializing in women's health from the Tamil Nadu Dr. M.G.R. Medical University, Chennai, Tamil Nadu, India.

She completed her certificate courses on teaching and learning from Laureate Faculty Development Program. She becomes a certified as a lamaze child birth educator soon. She is currently working as a senior lecturer in physiotherapy at the INTI-Laureate International Universities, Nilai, Malaysia. Her research interests in the field of physiotherapy are effects of maternal exercise on the fetus, incontinence, fitness. In physiotherapy education, she has inquisitive research interests such jigsaw learning, use of black board compared to traditional teaching methodologies, assessment strategies for active learning methods. She was a nominee for Teaching Excellence Award of 2013. 